present in the mind of the individual reflecting collective experience of the direct and indirect (in the process of upbringing and education) interaction with the environment. This conceptual system itself is the object of interaction.

Linguistic ecology dynamically reflects natural changes of linguistic conceptualization of the world, the relationships between social, cultural and linguistic processes. In this regard, it should be noted that this field has vividly marked interdisciplinary character, integrating diverse knowledge of humanitarian nature.

In linguistic ecology functions a number of interdisciplinary phenomena and their respective terms, which are in a state of constant interaction and intersect with different linguistic fields of terms. Thus, linguistic ecology relates to the field of complex and multifaceted phenomena of culturological and humanitarian character.

\title{
References:
}

1. Кравченко А. В. Знак, значение, знание: очерк когнитивной философии языка. Иркутск: Иркутская областная типография 2001. № 1.261 c.

2. Lakoff G., Johnson M. Metaphors we live by. London: University of Chicago Press, 2003. 276 p.

3. Maturana H., Varela F. The Tree of Human Understanding. Boston, 1987. $224 \mathrm{p}$.

DOI https://doi.org/10.30525/978-9934-26-073-5-2-18

\section{ТЕКСТ ЯК РЕЗУЛЬТАТ І ОДИНИЦЯ КОМУНІКАЦЇ̈: СТРУКТУРНО-СЕМАНТИЧНИЙ АСПЕКТ (РОЗГЛЯНУТО ШЛЯХОМ КОМПАРАТИВНОГО АНАЛІЗУ ФУНКЦІОНУВАННЯ СКЛАДОВИХ КОМУНІКАТИВНОГО ПРОЦЕСУ)}

\author{
Чубай B. I. \\ стариий інспектор відділу науково-дослідної роботи \\ Начіонального лінгвістичного університету \\ м. Київ, Україна
}

Наше спілкування пов'язано з відтворенням мовного коду і полягає у площині фреймових ситуацій, тому темою дослідження обрано складові комунікативного процесу. Складові комунікативного процесу розглянуто 
як соціальне явище, задіяного у взаємодію спілкування людей та засобів відтворення їх уяви 3 врахуванням когнітивних процесів. Однією 3 основних проблем при вивченні будь-якої мови є вивчення системних відносин між мовними одиницями [2, с. 35-36]. Вивчення системного характеру словникового складу мови полягає в розподілі лексем за частинами мови, за смисловими, морфологічними, синтаксичними словотворчими критеріями [2, с. 295-299]. Шляхом компаративного аналізу розглянута система відповідностей та розбіжностей складових тексту i дискурсу. Визначена категоріальна організація засобів вираження семантико-граматичних категорії тексту.

Складність дослідження складових комунікативного процесу (дискурсу, тексту, фрази) полягає у їх розмитих категоріях та функціях стосовно взаємодії синтаксису та лексики (полісемії та омонімії) [2, с. 185-187].

Якщо розглянути текст як результат i одиницю комунікації, необхідно зазначити, що текст це послідовність знакових одиниць, які об'єднані смисловим зв'язком, основні риси яких є зв'язність і цілісність. «Літературознавчий словник-довідник» зазначає, текст має походження від латинського слова textus, що в перекладі значить тканина, сплетення i тлумачить текст як результат спілкування (інтеракції і трансакції), його структурно-мовної складової і одночасно кінцевої реалізації; структура, в яку втілюється «живий» дискурс після свого завершення [3, с. 196-652]. Але, під таке саме визначення підпадають також i дискурси, що пояснюється розмитістю дефініцій тексту і дискурсу. Текст пов'язаний 3 інтеракціями, а дискурс - 3 трансакціями. Обидва поняття відтворюються у формі повідомлення та висловлювання (реченнями або фразовими комплексами). Різноманітність підходів до тлумачення тексту зумовлена багатьма причинами, передусім важливістю цього поняття для людини, його складністю, та багатовіковою традицією вивчення у різних сферах діяльності. Текст виконує різноманітні функції: бере участь у комунікації, допомагає зберігати і передавати інформацію в просторі й часі, фіксує психічне життя індивідів, є продуктом конкретної історичної епохи, формою існування культури, віддзеркаленням певних соціокультурних традицій [1, с. 291-349]. У сфері комунікації немає єдності поглядів щодо визначення текстів, так одні ототожнюють процес спілкування 3 текстом, вважаючи його втіленням самої комунікації [2, с. 11-15]. Інші розглядають текст як результат спілкування, співвідносячи його з поняттям «дискурс». Текст, як один із компонентів твору, за стилем походження може бути науковим, технічним, художнім. Текст, як лінгвістичне явище, характеризується такими ознаками: 
зв'язністю, цілісністю, емотивністю (авторською метою), інформативністю, ситуативністю (зв'язністю $з$ контекстом), членованістю (наявністю смислових частин), інтегрованістю (єдністю цих частин), модальністю (особистісним ставленням), розгорнутістю, послідовністю, динамізмом зображуваного тощо. Найголовнішою ознакою тексту є зв'язність і цілісність, тому, що зв'язність - це категорія, що характеризує особливість поєднання цілісності тексту його концептами, цілісність $€$ категорією, яка пов'язана зі смисловою єдністю. Текст може бути зв'язний, але нецілісний i, навпаки, цілісний, але незв'язний. Якщо провести компаративний аналіз визначення тексту і дискурсу, можемо зробити висновок, що між ними існують певні відмінності. Так, текст $\epsilon$ предикативною одиницею, в той час як дискурс $є$ мовленнєвою дією, або мовленнсвим актом. Текст утворює висловлювання автора, а дискурс передає комунікативний хід. Текст має діалогічну єдність, а дискурс носить характер інтеракції. Текст поділяється на абзаци, а дискурс на трансакції. Складовими текста $є$ макротекст, а дискурсу - макродіалог або мовленнєва подія. Дискурс більш динамічний, так як пов'язаний $з$ мовою діяльністю у процесі іiі реалізації, а текст є результатом цього відтворення у статичному вигляді. У тексті, на відміну від дискурсу, не виявляються паралінгвістичних засобів. Текст $є$ одиницею лінгвістичного методу, а дискурс - комунікативного. Текст і дискурс розглядаються як відповідники речення і висловлювання. Висловлювання об'єднує саме речення і соціальний контекст його використання. Текст одиниця лінгвальна, дискурс - соціолігнвальна, інтерактивна (трансактивна). Термін дискурс, на відміну від терміну текст, не застосовують до давніх текстів, зв'язки яких із життям не відтворюються безпосередньо. Текст і дискурс пов'язані між собою як процес і його результат. У зупиненому вигляді текст перетворюється на структуру з певними характеристиками. Потрапляючи до читача, текст наповнюється особистісними інтенціями і смислами авторського стилю і стає джерелом новоутворених дискурсів.

Якщо зауважити, що загальна система мови складається 3 чотирьох рівнів: фонологічного, морфологічного, лексико-семантичного, синтаксичного, то необхідно зазначити, що кожен рівень маю свою одиницю: фонологічний - фонему, морфологічний - морфему, лексико-семантичний - лексему (слово), синтаксичний - речення [2, с. 34]. Так, як текст складається 3 моно- та багатокомпонентних речень, фразових одиниць, які складають фразовий комплекс, тому можемо розглядати текст за синтаксичним критерієм. Буде доречним розглядати внутрішню структуру тексту за семантично-синтаксичним 
критерієм [2, с. 295-297]. Головними одиницями тексту є лексема, і тому текст також може розглядатися за лексико-семантичним критерієм. Враховуючи той факт, що лексичне значення полягає в двох планах вираження і змісту, яке в тексті відтворюється в конотативного та контекстуальному значенні 3 врахуванням смислового навантаження [2, с. 187-187]. Ще однією особливістю парадигми тексту є концептуальне значення, що складається 3 текстових компонентів і фреймових ситуацій і разом складають єдність і цілісність тексту [4, с. 66-68]. Концептуальне значення є ядром лексичного значення [2, с. 188]. Таким чином, відтворюється концептосфера тексту як продукт когнітивної діяльності людей. Отже, можемо визначити складову парадигми тексту за: лексичним, концептуальним, конотативнтим та контекстуальним значеннями. Таким чином, можемо зазначити, що головними ознаками тексту є комунікативність, предикативність, модальність, структурна цілісність.

У науковій літературі існують класифікації текстів за соціолінгвістичними, психолінгвістичними, власне комунікативними, функціонально-прагматичними, синтаксичними критеріями, а також за граматичними категоріями [2, с. 20-21]. Якщо розглядати текст за функціонально-прагматичним критерієм, то необхідно визначити такі категорії як цілісності та єдності (тематична, комунікативна, структурна). За тематичною єдністю текст має такі категорії як глибинного смислу, смислової та логічної побудови. За комунікативною єдністю текст здійснює комунікативний та естетичний вплив. За структурною єдністю він має граматичні, лексичні та фонологічні категорії. За тематичною єдністю текст охоплює психологічну категорію (концепт тексту), його смислову (змістову структуру елементів тексту) і логічну будову (послідовність і структуру представлення смислових елементів у процесі розгортання тексту). За комунікативною єдністю визначається комунікативна цілеспрямованість тексту. Будь-який текст повинен впливати на його реципієнта. Комунікативний вплив спричиняє ментально-вербальну або фізичну реакції; естетичний - ментально-емоційну реакцію. За структурною єдністю текст має конкретно-знаковий вираз у вигляді мовних засобів, які класифікують за мовними (рівневими) ознаками: фонеми, лексеми, синтаксеми. Функціонально-прагматичний критерій враховує суб'єктивну міжособистісну модальність, дозволяє стверджувати про деонтичні (нормативні, приписові, договори, державні акти, постанови, інструкції, накази), аксіологічні (оцінні) та епістемічні (дескриптивні, описові), тексти (наукові, ділові тощо). 
Актуальність дослідження зумовлена необхідністю: проведення аналізу мовленнєвої комунікації, які спостерігаються в мові; дослідження взаємовпливу між текстом і дискурсом; визначення практичних завдань дослідження складових комунікативного процесу. Методологічну основу дослідження становлять провідні принципи системності, єдності форми та змісту, використання методів і прийомів - лінгвістичного спостереження, застосування індуктивного та дедуктивного методу аналізу, в опрацюванні компаративного аналізу. Розглядалися такі складові комунікативного процесу, як дискурс, текст. Дискурс розглянутий як тип комунікативної діяльності, текст як одиниця комунікації. Шляхом структурного аналізу визначено структуру та особливості побудови. Залучивши компаративний аналіз визначено типологію та особливості функціонування складових комунікативного процесу.

\section{Література:}

1. Корунець I. В. Вступ до перекладознавства. Виниця. ПП «Нова Книга», 2008. 510 с.

2. Кочерган. М. П. Вступ до мовознавства. Київ. Видавничий центр «Альма Матер», 2006. 367 с.

3. Літературознавчий словник-довідник. Київ, Видавничий центр «Академія», 1990. $751 \mathrm{c}$.

4. Савчук Р. І. Особливості побудови концептуального мегапростору художньої прози Ф. Саган. Наукові записки Чернівецького університету, 2009. № 484. C. 66 - 69 URL : http://www.irbis-nbuv.gov.ua/cgibin/irbis_nbuv/cgiirbis_64.exe?C21COM=2\&I21DBN=UJRN\&P21DBN=UJ RN\&IMAGE_FILE_DOWNLOAD=1\&Image_file_name=PDF/Nvchu_rsd_2 009_484_16.pdf (дата звернення 02.11.2020). 